\title{
Why Do African Countries Adopt IFRS? An Institutional Perspective.
}

Pran K. Boolaky, Vincent Tawiah and Teerooven Soobaroyen

\begin{abstract}
We examine the institutional drivers of International Financial Reporting Standard (IFRS) adoption in Africa. The study covers all 54 African countries and relies on data from 2010 to 2015. Our results support the neo-institutional theoretical predictions that coercive, mimetic, and normative isomorphism influence IFRS adoption in Africa, although the circuits of isomorphic pressures differ from previous studies investigating adoption at the worldwide level and in emerging economies. Specifically, we find evidence of the influence by the World Bank (WB) and International Monetary Fund (IMF) on African countries made subject to the Report on Observance of Standard and Codes (ROSC) Accounting and Auditing program of assessment. We also found that the presence of global audit firms and the number of years of IFAC membership are strongly associated with a country's decision to adopt IFRS. Also, countries with a more structured and active professional accounting organization are more likely to adopt IFRS. Our findings provide insights into the significant role played by local professional accounting organizations in the promotion of IFRS. Furthermore, our study adds to the literature by providing empirical evidence that the nature of the isomorphic pressures in Africa are different from those suggested in prior studies and reinforces the view that IFRS adoption is primarily driven by social and political dimensions rather than the economic ones usually professed by IFRS proponents.
\end{abstract}

Keywords: Accounting; Africa; IFRS adoption; neo-institutional theory.

Acknowledgments. We thank Prof. Christoper Nobes from Royal Holloway University of London and A/Prof. Oksana Kim from Minnesota State University for their useful comments and suggestions 


\subsection{Introduction.}

Over the last few decades, the African continent has become more globally connected through foreign investments and trade. For example, Foreign Direct Investment in Africa increased from US \$ 14 billion in 2004 to US \$ 73 billion in 2014, and Initial Public Offerings (IPOs) grew by $17 \%$ over the same period (PWC, 2017). One factor purportedly attributed to the rise of foreign investment and trade is the availability of financial accounting information to underpin the decisions by investors and international suppliers/customers (Nnadi and Soobaroyen, 2015). Specifically, and over the last twenty years, IFRS diffusion has been characterized as a global endeavor to harmonize disparate accounting practices mandated in local standards and hence facilitate the global flow of investment and trade (Chua and Taylor, 2008; Alon and Dwyer, 2014). At the global level, 65\% of countries have adopted IFRS. Contrastingly, as of 2015, only one-third of African countries adopted IFRS in its fully-fledged form (18 out of 55 countries) and $48 \%$ of the countries on the continent use local accounting standards. This brings to the fore the question of what factors might be associated with the decision to adopt (or not) IFRS. Consequently, this paper aims to provide insights into the factors that are associated with IFRS adoption in Africa.

Following Judge, Li Pinsker (2010) and other work examining the dynamics of IFRS adoption (e.g. Alon and Dwyer, 2014; Hassan, Rankin and Lu, 2014; Nurunnabi, 2015), the paper draws from neo-institutional theory. According to this perspective, nation-states are conceptualized as social actors that seek legitimacy and social acceptability, and as such, they are subject to transnational, international and national forces (or constraints). These forces (or constraints) bring about a wide array of pressures that shift countries towards the adoption of similar practices (i.e. isomorphism) within a given institutionalized environment of global norms, customs and rules of governance (Chua and Taylor, 2008; Alon and Dywer, 2014, Nurunnabi, 2015; Hopper, Lassou and Soobaroyen, 2017). Conceptually, DiMaggio and Powell (1991) 
classify isomorphism into coercive, mimetic and normative pressures. In this context, coercive isomorphism emanates from a financial dependency and other conditions associated to support from donor nations or international financial institutions such as the World Bank (WB) and the International Monetary Fund (IMF), and is measured as the total commitment from foreign donors and the nature of recommendations from their Reports on Observance of Standards and Codes (ROSC) relating to a given country (Chua and Taylor, 2008). Mimetic isomorphism arises from the replication of practices across nations whereby there is tendency to emulate what more successful countries have done to secure benefits and social acceptance (Nurunnabi, 2005), often as a result of initiatives championed by national 'enabling' organizations that are affiliated to international IFRS 'champions' (Chua and Taylor, 2008). This was measured as the number of years the country has been a member of the International Federation of Accountants (IFAC) and the number of international audit firms operating in the country. Lastly, normative isomorphism refers to the role and influence of professionalization processes led by local bodies and/or institutions (e.g. universities, regulators) that establish what is required of a qualified accountant (Hassan et al., 2014). This is measured by the number of qualified accountants and the strength/level of structuring of the professional accounting organization (PAO). Drawing from prior findings on IFRS adoption (Judge et al. 2010; Ben Othman and Kossentini, 2015), we controlled for import penetration, growth rate of gross domestic product, prevalence of foreign ownership, market capitalization and colonial history. As of 2015, only 18 African countries have mandated IFRS for all listed and large companies, whereas 6 countries require some companies to use IFRS. Only 5 countries allow voluntary adoption but 25 countries have not committed to the use of IFRS. Coercive, mimetic, and normative pressures are found to be associated with IFRS adoption in Africa, albeit that the 'circuits' of pressure differ from prior studies (e.g. Judge et al. 2010). In particular, our results show IFRS adoption in countries where the WB/IMF recommended IFRS adoption (in their 
ROSC reports) and where there were more global audit firms. Countries having longer IFAC membership and stronger PAO are also more likely to adopt IFRS. As a robustness test, a firmlevel analysis reveals that African companies that voluntarily adopted IFRS have a larger number of chartered accountants on the board and have been audited by one of the Big Four firms. The results are robust when considering alternative measures and econometric models.

Our findings contribute to the literature in the following ways. First, we complement the crossnational insights by Judge et al. (2010), Koning et al., (2018) and Ben Othman and Kossentini, (2015) by emphasizing the incremental socio-political, rather than purely economic, dimensions of the determinants of IFRS adoption in Africa associated to both transnational and national sources. These prior studies highlighted foreign aid, import penetration, trade freedom, and secondary school education. However, IFRS adoption in Africa seems to be predicated on the existence of coercive pressures from IMF/World bank, mimetic pressures via IFAC membership and normative pressure from the strength of PAOs. These findings chime with some of the few single-country case studies (e.g. Hassan et al., 2014; Nurunnabi, 2015). Secondly, our results bring to the fore the regional specificities as to the nature and type of pressure underlying IFRS adoption and hence strengthen calls for studies that can capture the unique features and dynamics of accounting practices in Africa (Rahaman, 2010; Lassou and Hopper, 2016). This also raises questions about the monolithic use of generalized proxies and assumptions that consider institutional frameworks in Africa to be similar to other regions.

The remainder of this paper is organized into five sections. Section 2 reviews the literature; Section 3 sets out the theory and hypotheses development; Section 4 describes the research methodology; Section 5 reports the results with interpretations; Section 6 presents the conclusion. 


\subsection{Literature review}

\subsection{Empirical literature on the institutional determinants of IFRS.}

In relation to the determinants of IFRS adoption, Judge et al. (2010) examined the relevance of isomorphic pressures for a sample of 132 countries and found that foreign aid, import penetration, and educational attainment, are respectively and significantly coercive, mimetic and normative predictors of a country's decision to adopt IFRS. A crucial point by the authors is that these factors are observed to be more significantly associated to a country's level of IFRS adoption compared to the 'traditional' legal and cultural variables used by Ding, Jeanjean, and Stolowy (2005) and Hope and Kang (2006). These factors are rooted in historical, and arguably increasingly less relevant, circumstances. Notwithstanding evidence of an existing debate about whether weak investor protection rules/legal origin 'outweigh' cultural dimensions (refer to Hope and Kang 2005; Ding et al., 2005) as factors influencing IFRS adoption, Judge et al (2010) revealed that normative isomorphism (educational attainment) has the strongest influence on IFRS adoption. Judge et al. (2010) argued that the peculiarity of this result may be related to an observation that the accounting profession is more susceptible to normative pressures relative to other institutional norms "because professional norms and practices are supposed to transcend national beliefs and common practices." (p. 169). Whilst the authors do offer some anecdotal evidence (US/Japan), there is a scope to investigate whether there is a normative 'circuit of professional influence' by relying on more specific measures of country-level accounting professionalization.

At the same time, and partially in response to Chua and Taylor's (2008) calls to study the international diffusion of IFRS and Judge et al.'s (2010) findings, several studies sought to investigate the dynamics of how and why does IFRS disseminate in developed as well as developing countries. Alon and Dywer (2014) study the specific case of early adoption by a 
sample of 71 countries and inferred that countries with weaker governing structures and lower level of economic development tend to adopt IFRS earlier because of a presumed need for legitimacy and resources from international financial institutions (e.g. WB \& IMF). However, the authors do not directly measure the extent of such a dependence towards these institutions. Koning et al. (2018) also assessed the transnational drivers of IFRS adoption in a large sample of 168 countries and found that IFRS adoption is not influenced by local determinants but by the policy diffusion forces of learning, competition, and emulation among countries. Hence, countries tend to adopt IFRS through learning or competing with an IFRS-adopted country and there is little evidence of a coercive effect (e.g. from international financial institutions). Although the results largely support the neo-institutional perspective, we contend that their findings might be more relevant to the case of developed countries that already have established local settings, such as professional accounting organizations, regulatory framework for accounting and auditing services, presence of large international accounting firms in addition to a well-developed accounting education system (academically and/or professionally).

Contrastingly the case may be different in developing countries due to the absence of strong local institutional structures and IFRS may not be diffused in the same way as argued by Koning et al. (2018). In this regard, local factors, as argued by Ball (2006) and Alon and Dwyer (2014), may predominate. For instance, IFRS adoption may be associated to the state of national institutions irrespective of what neighboring countries have decided i.e. whilst there may be an interest towards learning, competition, and emulation, national institutional structures may not be necessarily equipped (or be well developed) to do so (refer to Hopper et al., 2017). Thus, local factors, such as the influence of the national professional accounting organizations (PAOs) and professional accountants, may remain the driving force behind IFRS adoption in developing countries. Notwithstanding, an early study by Zeghal and Mhedhbi (2006) revealed a significant positive association between educational levels, the existence of 
a capital market, and cultural closeness to Anglo-American culture, and a country's IFRS adoption decision, thereby highlighting the relevance of a combination of economic and cultural variables. It is acknowledged that the extent of IFRS adoption amongst developing/emerging economies at the time of the study was not so prevalent and inherently excluded many African countries.

In this regard, Ben Othman and Kossentini (2015) rely on a larger sample of 50 emerging economies (including nine African countries) by also relying on neo-institutional theory. They used foreign aid and the use of ROSC reports as a proxy for coercive isomorphism, trade freedom, and the density of the Big Four auditing firm offices as mimetic isomorphism variables, and IFAC membership and the number of certified public accountants (CPA) per population as normative proxies. Their study revealed that both coercive and mimetic isomorphism are significant and are positively associated with a country's IFRS adoption decision. Consistent with Ritsumeikan (2011), Judge et al. (2010), Boolaky (2012), and Albu et al. (2011), Ben Othman and Kossentini (2015) find support for the coercive and mimetic nature of the institutional pressures on IFRS adoption in emerging economies. At the same time, Ben Othman and Kossentini (2015) reported a significant negative association between normative isomorphism and IFRS adoption, implying that the higher the number of accounting professionals in an emerging country, the less likely a country will to adopt IFRS. The authors inferred that for countries that faced a lack of qualified professional accountants are more likely to adopt IFRS due to the limited capacity to develop their own national standards. Ritsumeikan (2011) attempted to apply Judge et al.'s (2010) model to the case of emerging economies and found a stronger association for coercive isomorphism, albeit that the results appear to be influenced by the weak proxies for the mimetic and normative dimensions.

Whilst these results highlight the specificities of developing/emerging countries in relation to IFRS adoption, the findings remain mixed in terms of the relevance of various 
pressures and factors. The role of transnational institutions, as a coercive pressure, has been alluded to in several single-country studies (e.g. Romani - Albu et al., 2011; Iraq - Hassan et al., 2014; Bangladesh - Nurunnabi, 2015), and merits further analysis; particularly with reference to the African context.

\subsection{Empirical literature on IFRS adoption in Africa}

A few studies have assessed the adoption and development of accounting standards in Africa, and have predominately examined the development of accounting or consequence of IFRS in a particular country or regional setting. For example, Assesnso-Okofo, Ali and Ahmed (2011) documented that both institutional and political pressures significantly influenced the transition of local accounting standards towards IFRS in Ghana, but the regulatory environment to enforce it is fragile. In a similar vein, Bova and Pereira (2012) found that institutional structures, such as the type of corporate ownership, shaped the adoption, compliance, and consequences of IFRS in Kenya. Stainbank (2014) investigated the case of 32 African countries and identified a number of economic motivations (faster economic growth rates, market capitalization) underlying IFRS adoption, in addition to the observation that countries having cultural ties with the United Kingdom (as ex-British colonies) were more likely to adopt IFRS.

The above results do highlight the continued relevance of colonial influence in Africa, although it is not always clear how this influence is enacted or persists post-independence. In spite of a number of internal and external pressures, the accounting structures of most African Francophone countries are, for instance, still shaped by the long-established traditions and advisers directly from their ex-colonizer, France (Elad, 2015). In particular, Degos et al. (2018) argue that African French-speaking countries followed a different path to English-speaking countries in their relatively slow progress towards full IFRS adoption and convergence. They identified a number of inter-related factors namely the continued interaction/influence of French institutions on the development of local accounting standards, the academic and 
professional accounting educational structures and the role of key consultants/actors in the field.

Lastly, some single-country studies in Africa do emphasize the direct lobbying efforts from international financial institutions with respect to IFRS adoption, particularly in the context of the WB and/or the IMF's interventions on structural adjustment and assistance programs (Rahaman, 2010; Hopper et al. 2017). For example, Hassan (2008) highlighted that foreign aid provided by the IMF had been a key influential conduit through which Egypt was pressured to move towards IFRS. More recently, Zori (2015) reported that the adoption of IFRS in Nigeria was a core component of WB-funded Economic Recovery and Governance Programme (ERGP) instigated by international institutions in return for financial assistance. Alongside other similar cases in the developing world (Hassan et al., 2014; Nurunnabi, 2015) and observations that a number of transnational governance bodies (e.g. Financial Stability Board, European Union, International Organisation of Securities Commissions) have become more vocal in their support for the adoption of, or convergence to, common accounting, auditing and governance standards (Alon and Dywer, 2014), we contend that there is a need to investigate more generally the extent of the influence of transnational players on IFRS adoption in Africa.

\section{Theory and hypothesis development}

\subsection{Background of neo-institutional theory}

Neo-institutional theory remains one of the most commonly used theoretical perspectives in analysing how organizations embed rules, beliefs, and cultural norms (Lounsbury and Zhao, 2013). According to this theory, institutions or organizations themselves are actors who facilitate growing similarities within a particular field (DiMaggio \& Powell, 1991). Although the neo-institutional perspective is primarily drawn from cognitive and social 
psychology, anthropology and political science, it has been applied in other areas including management and accounting. Prior studies have used the neo-institutional perspective to establish the nature of internal and external institutional pressures driving the adoption of particular regulations and practices (Tauron, 2005). For example, Guler, Guillen, and Macpherson (2002) posited that the adoption of ISO 9000 standards was influenced by institutional factors, as was the case for hostile takeover legislation and practices (Schneper and Guillen, 2004).

The development of accounting standards and its adoption (at national and organizational levels) also follow a similar trend (Mueller, Gernon, and Meek, 1994). Rodrigues and Craig (2007) define institutionalization in the global accounting context as the social process through which countries accept that their local standards need to be replaced by international standards, ostensibly to achieve a global harmonization of accounting practices and standards. Early scholars, who examined the process of harmonization of accounting standards, revealed that country-specific characteristics such as legal, cultural, economic, historical and political features do, to a varying extent, influence a country's decision to adopt or not a new accounting practice or system (Ding et al., 2005; Hope et al., 2006; Boolaky and Soobaroyen, 2017; Archambault and Archambault 2009; Zarzeski 1996). However, these dimensions often reflect structural conditions within a jurisdiction and offer only limited, and sometimes contradictory explanations. Instead, what is needed is a better understanding of the contemporary and dynamic forces behind what has been labelled as an unusually fast rate of IFRS adoption worldwide (Chua and Taylor, 2008; Judge et al., 2010; Alon and Dywer, 2014).

We thus contend that a key assumption underlying the neo-institutional perspective is that participants seek legitimacy from the prevailing institutional environment by conforming to particular standards of behaviour that are themselves seen to be appropriate and socially acceptable (Judge et al., 2010; Alon and Dywer, 2014). In turn, the maintenance or gain in 
legitimacy provides participants with benefits, access to resources and ensure survival. Scott (1987) also conceptualized an institutional environment as a sustainable system of socially organized practices and social benefits associated with different functional areas of the society. Following this concept of institution and his prior studies on institutionalism, Scott (2001), presents a three-level theoretical framework which elaborates how the higher institutional environment affects lower institutions. Consistent with previous institutional theory insights relating to the diffusion of IFRS at the national level (e.g. Judge et al., 2010; Alon and Dywer, 2014), the top-tier institutional environment consists of number of transnational and other societal bodies (e.g. WB, IMF) who use both formal and informal communications, recommendations and proposals to shape structures and environments of the lower level institutions. Governance structures including organizational fields and the organizations themselves are the next level of Scott's (2001) framework. Organizational field consists of organizations in the same arena on the basis of similar services provided or other common characteristics as well as influencing partners such as bankers. Each organization's behaviour influences or is influenced by others. For example, a poorly governed company may elect to adopt the practices of another company if it perceives the latter to be a successful and socially acceptable organisation. At the last level of the framework are groups of individuals and actors (including accounting bodies and professionals) who are the 'recipients' of the higher-order pressures to conform to institutional norms whilst also seeking to negotiate and influence the diffusion of these norms.

DiMaggio and Powell (1983) argued that these long-term interactions within an institutional environment lead to increased similarities in norms and practices across different institutional contexts (isomorphism) through three 'circuits', namely coercive isomorphism, mimetic isomorphism, and normative isomorphism. Admittedly, these three classifications of isomorphic pressures are not always empirically distinct. They intermingle in empirical 
settings, but since each pressure drives, and is driven by, different conditions, it is possible that these can lead to different outcomes.

\subsection{Coercive Isomorphism}

Coercive isomorphism is the result of both formal and informal pressures exerted on organizations by other organizations upon which they are dependent (DiMaggio and Powel, 1983, p. 150). Coercive isomorphism is premised on a financial and technical dependency that makes organizations subject to the demands of resource suppliers. That is, higher institutions can exert pressure on lower institutions due to the latter's dependence on higher institutions for support (Mir and Rahaman, 2005; DiMaggio and Powell, 1991). In this regard, International Financial Institutions (IFI) require developing countries to implement reforms and/or fulfil conditions to be eligible for funding (Rodrigues and Craig, 2007; Wyatt 1997). Arguably, this higher financial dependency between these IFI and African countries creates a 'conditionality' for IFI to exert pressure on the adoption of standards such as IFRS, as was reported in the case of Ghana (Assenso et al., 2011). The WB loan or grant usually requires countries to reduce budget deficits, restructure foreign debts, devalue the currency, in the longer-term privatize state-owned companies, and implement anti-corruption and market liberalization laws (World Bank, 2005). Previous accounting research has also shown how IFIs influence the nature and operation of accounting practices in developing countries (Hopper et al., 2017) and in Africa (Rahaman, 2010). In this regard, authors such as Efobi (2015) and Nnadi (2012) reported that there have been increasingly persistent attempts by IFIs to press for the adoption of IFRS in developing countries (see also Hassan, Rankin, \& Lu, 2014; Tyrrall, Woodward, \& Rakhimbekova, 2007; Touron, 2005).

A key historical juncture underlying this persistence, and which is often referred to in the literature, is the Asian financial crisis of the late 1990s (Chua and Taylor, 2008; Alon and Dwyer, 2014). The crisis and its aftermath revealed the interconnectedness of financial, 
banking and economic systems across developed and developing countries due to the quasifree circulation of financial flows worldwide. A domestic crisis in a country with weak governance, accounting and/or regulatory structures could thus spread rapidly to other countries and create regional and international financial instability. Since the WB and the IMF are in effect tasked to support countries in times of crises, a determined and strategic approach was put in effect to strengthen accounting, governance and regulatory systems worldwide, with a particular emphasis on developing countries (Mir and Rahaman, 2005). A few transnational governing bodies and associations also emerged as powerful supporters of the WB/IMF initiatives, such as the Financial Stability Board (FSB), International Federation of Accountants (IFAC), International Organizations of Securities Commissions (IOSCO) and Organization for Economic Cooperation and Development (OECD). This renewed emphasis by WB/IMF, supported by these organizations, precipitated efforts to diffuse a common set of financial and regulatory standards ${ }^{1}$ including IFRS (Chua and Taylor, 2008; Alon \& Dwyer, 2014).

A crucial mechanism underlying this coercive circuit has been the Report on the Observance of Standards and Codes (ROSC) program jointly run by the WB and IMF. First launched in 1991, the Accounting and Auditing (AA) assessments investigated the accounting, auditing and regulatory framework of a given jurisdiction and also reviewed a sample of financial statements of local companies, which concluded with an evaluation and recommendations. Almost 200 assessments and reports (twice for some countries) were carried out followed by regular discussions with countries, inclusive of the need to engage with IFRS. For instance, Zori (2015) claims that the 2004 ROSC (AA) on Ghana and Nigeria was the trigger for the two countries' IFRS adoption in 2007 and 2012 respectively. Although the

\footnotetext{
${ }^{1}$ For example, International Standards on Auditing (ISAs), Principles of Corporate Governance, Insolvency and Creditor Rights Standard, Code of Good Practices on Transparency in Monetary and Financial Policies. In total, the Financial Stability Board recommends the adoption of 12 key standards for ensuring sound financial systems.
} 
ROSC reports only provide recommendations, the WB and IMF do rely on the latter to underpin discussions with countries and as the dominant transnational players, they seek to establish a commonly understood societal framework for behavior (Alon and Dywer, 2016). In addition to the fact that countries in need of financial assistance might be expected to adhere to the relevant conditions to secure financial assistance and adopt IFRS accordingly, the neoinstitutional perspective suggests that nation-states that have been subjected to a scrutiny of their accounting and auditing systems (ROSC reports) would be more likely concerned about the state of their legitimacy vis-à-vis the transnational institutional environment. We therefore formulate the following hypothesis in respect to coercive pressures from international financial institutions:

$H_{1}$ : The likelihood of a country's IFRS adoption is associated with the existence of external pressure from international financial institutions to conform to globally legitimized models of accounting systems.

\subsection{Mimetic isomorphism}

DiMaggio and Powell (1983, p. 152) explained that mimetic isomorphism arises because "organizations tend to model themselves after similar organizations in their field that they perceive to be more legitimate or successful." Organizations (and nations) that do not have defined policies of their own are more likely to import existing institutionalized policies, mainly as a result of availability, certainty, and low cost. Mir and Rahaman (2005) argued that that the reliance on 'off-the-shelf practices is a common mode of diffusion of international practices among developing countries. In this context, the role of global audit firms and their affiliated networks/firms in developing countries has been highlighted as a significant factor in translating and communicating the benefits of IFRS to a wider constituency of policymakers, regulators and companies at the national level. Although global audit firms do not have the power to enforce any set of accounting standards on a country, they rely on the prominence 
and expertise of their professionals and their involvement in the accounting and audit of listed companies to advocate IFRS as a route to adopting high-quality accounting standards (Assenso et al., 2011). On a related point, Chua and Taylor (2008) mention how global audit firms advocated IFRS as a way to facilitate the financial reporting requirements for multinational firms and this gradually led to a situation where the global audit firms portrayed IFRS as the most appropriate set of accounting standards for domestic listed companies. This reinforced the global firms' (and their national affiliates/networks) own market dominance due to their existing expertise on IFRS implementation and audit. In this respect, Albu et al. (2011) claimed that in Romania, the Big Four firm's drive for globalized accounting standards was a source of pressure on Romania to adopt IFRS. In a similar vein, Joshi et al. (2008) highlighted the influential role of the Big Four in Bahrain's adoption of IFRS. Furthermore, Ben Othman and Kossentini (2015) demonstrated that the presence of the Big Four audit firms was positively and significantly to IFRS adoption in emerging economies. In effect, the presence of global audit firms in the national context signals the extent of country's integration with the global accounting community and in turn, this leads to a diffusion of 'international' norms of behaviour. Respectively in the case of Egypt and France, Hassan (2008) and Touron (2005) concurred that there was a strong impetus by local bodies and practitioners to mimic the global audit firms and adopt international standards in a bid to be seen as more 'relevant' and 'professional'.

The role of global audit firms in contributing to the mimetic pressures to adopt IFRS is supported by other transnational professional organizations and institutions (Chua and Taylor, 2008). In particular, IFAC has gradually positioned itself as key transnational professional agency not only in terms of the rapid development of the International Standards on Auditing (ISAs) (Humphrey et al., 2009; Boolaky and Soobaroyen, 2017; Boolaky, Ghattas, Marnet and Soobaroyen, 2020) but also in terms of taking the lead on a number of initiatives relating to the 
establishing of an International Accounting Education Standards Board (McPeak et al., 2012) and a model code of ethics for professional accountants (Clements et al., 2009). In this way, IFAC aims to institutionalize a set of norms and 'best practices' in terms of how national professional accounting organizations might seek to define or conceptualize the various aspects and dimensions of 'professional accountancy'. As an institutional member of IFAC, a national organization would rely on these pronouncements and guidance documents to ensure they operate in line with international norms. In this respect, professional accounting bodies seeking legitimacy, influence and recognition on the global stage are more likely to adhere to IFAC's expectations and place more emphasis on international accounting standards than local accounting standards. As in the case of the global audit firms, IFAC does not have any direct authority to influence the adoption of accounting standards of a country. However, affiliation to IFAC leads to influence in terms of the local professional accounting community being more aware of the practices being adopted by other national accounting associations and thereby for it to consider appropriate to adopt the same practices. Following Judge et al. (2010), we therefore hypothesize the relationship between mimetic pressures and IFRS adoption in this form:

$\mathrm{H}_{2}$ : The likelihood of a country's IFRS adoption is associated with the extent to which it is integrated within the global accounting community.

\subsubsection{Normative isomorphism.}

DiMaggio and Powell (1983) contend that normative isomorphism arises from the collective struggle of members of an occupation to define the conditions and methods of their work and to control the production of their products/services. These collective struggles and values help the organization to derive legitimacy from their occupational autonomy and expertise (Larson, 1977). Thus, normative isomorphism stems from a professionalization process whereby a form of 'professional monopoly' is “facilitated through jurisdictional claims 
which focus on the content, control, and differentiation of work" (Sian, 2006, p. 296). The accounting profession in many countries has been particularly successful in ensuring that this monopoly in the provision of 'qualified accountant' services is maintained through the use of credentials, examinations, and/or registration that are typically endorsed by the State (Birkett and Evans, 2005). In this way, accounting education, including professional training, is able to exert influence towards the standardization of accounting practices (and accounting standards) among organizations within the same field (Hassan, 2008).

Hegarty, Gielen, and Barros (2004) asserted that the adoption of IFRS would require a minimum level in terms of the educational system and a relatively large number of qualified professionals. In this regard, Judge et al. (2010), Zeghal and Mhedhbi (2006) and Ritsumeikan (2011) found a strong positive and significant association between educational levels and IFRS adoption. Furthermore, several authors have argued that qualified accounting professionals, as well as professional training, are key ingredients for effective implementation of IFRS in developing countries (Phuong \& Nguyen, 2012; Muniandy and Ali, 2012; Albu et al., 2011; Perumpal et al., 2009). Zeghal and Mhedhbi argued that the adoption of IFRS requires a high level of education, competence, and expertise, to be able to understand, interpret, and make use of the standards. However, according to several ROSC reports, accounting education at the secondary and university levels in Africa remains insufficient or inexistent (ROSC, 2004-2015) and in the case of many developing countries that have decided to adopt IFRS, there appears to be little in the way of a coherent and national programme of professional development to underpin IFRS implementation (Hassan et al., 2014; Nurunnabi, 2015; Hopper et al., 2017).

Our contention is that the level of accounting education is closely related to the standing and competence of national professional accounting organizations (PAO) (Al-Akra et al. 2009, Assenso et al. 2011). The ROSC reports (ROSC, 2004-2015) have often highlighted the absence of a functioning local PAO in African developing countries and the situation that many 
qualified accountants are members of overseas accountancy bodies (e.g. Association of Chartered Certified Accountants, Institute of Chartered Accountants of England \& Wales); hence not technically and directly accountable to local settings. In such situations, the ROSC reports have typically recommended the setting up or strengthening of the local PAOs in many African countries to handle examinations, professional development/accreditation, ethics/disciplinary procedures as well as registration of local accounting firms and professionals. According to Al-Akra et al. (2009), the accountancy profession is crucial for the development of financial reporting and auditing practices and their existence and capabilities are integral to the adoption of IFRS. PAOs can also be considered to have higher levels of influence and structuring if they can operate their professional certification qualifications and Following Judge et al. (2010) we hypothesize for the relationship between normative pressures and IFRS adoption as follows:

$H_{3}$; The likelihood of a country's IFRS adoption is associated with the level of professionalization at the local level.

\subsection{Data and Methodology.}

The sample consists of all 54 African Union-recognized countries between 2010 and 2015. We obtain data from World Economic Forum, World Development Indicators, the World Bank ROSC website, iasplus.com, IFRS.org, PWC, IFAC membership profile, OECD statistics, and African countries' PAO websites. Our dataset yielded 270 observations.

\subsection{Measurement of Variables}

Countries adoption status (dependent variable-IFRS_AD); Although several studies (e.g. Hope et al., 2006; Judge et al., 2010; Alon and Dwyer, 2014) have used Deloitte's iasplus.com as the common source of jurisdiction adoption status, we argue that using only Deloitte's iasplus.com not only limits the classification but also appears to eliminate some countries from 
the sample. Therefore this study draws from five different sources to generate a country's adoption profile. Each source complements each other primarily because of the differences in the coverage of jurisdictions and helps to yield a comprehensive country profile. Admittedly, conflicting information about a country's level of IFRS adoption does emerge. In this respect, Ben Othman and Kossentini (2015) excluded countries such as Egypt due to discrepancies from different sources. Instead, this study followed the approach by Ramanna and Sletton (2014) in resolving conflicting information from different sources and applying a majority rule for countries that have conflicting information from these different sources. IFRS_AD was measured as binary variable; $1=$ for adopted countries and $0=$ non-adopted countries. We also extended the measurement on ordinal as 0 - countries that do not permit, 1 - countries that permit; 2 - countries that required by some companies; 3 - countries that required by all companies.

Coercive score (COC): Resource providers such as IMF and WB use different means to exert pressures on nation-states including terms and conditions on loans and financial support; recommendations and advocacy activities. For the adoption of rules, prior studies have argued that the most effective source of coercive pressure originates from the inclusion of IFRS adoption in the terms and conditions and/or as part of ROSC recommendations (Judge et al. 2010; Ben Othman and Kossentini (2015). Therefore, we construct a coercive score (COV) from the rankings on total commitments (TCC) from the IMF and WB and recommendations from the Report on Observance on Standard and Codes (ROSC). We used a percentile to rank countries on a scale of $0-3$ based on the level of total commitments received. Country $i$ is ranked 0 if TCC $<25^{\text {th }}$ percentile; $i=1$ if TCC $>25^{\text {th }}<50^{\text {th }} ; i=2$, if TCC $>50^{\text {th }}<75^{\text {th }} ; i=3$ if $T C C>75^{\text {th }}$ $<100^{\text {th }}$. Rankings based on ROSC were as follows; ROSC on a scale of 0-3 where $0-$ If ROSC was not issued in the country, 1- if ROSC was issued for the country, 2 - if ROSC recommended the development of accounting standards based on IFRS, 3 - if ROSC 
recommended the adoption of IFRS. COV was estimated as the average of these 2 rankings per country.

Mimetic score (MIM): The pressure to adopt practices by mimicking other organizations and nations on the global stage can be seen to originate from a variety of sources including FDI, the presence of multinational companies, membership in regional trading blocs, and the extent of import penetration (e.g. Judge et al., 2010). Insofar as accounting practices and standards are concerned, we contend that countries are more likely to be receptive from pronouncements and guidelines emanating from the global accounting community such as IFAC and international audit firms, particularly when these discourses are endorsed by a number of transnational governance bodies such as IOSCO, FSB and OECD. In this respect, we constructed a mimetic source (MIM) score from the average rankings of the number of 10 international accounting firms (IAF) in a given African country and the number years the local PAO has been a member of IFAC. We used percentile to rank countries on scale of 0-3 as follows: Country $i$ is ranked 0 if IFAC $<25^{\text {th }}$ percentile; $i=1$ if IFAC $>25^{\text {th }}<50^{\text {th }} ; i=2$, if IFAC $>50^{\text {th }}<75^{\text {th }} ; i=3$ if IFAC $>75^{\text {th }}<100^{\text {th }}$. Rankings based on international audit firms were as follows country $\mathrm{i}=0$ if IAF is $0-1 ; i=1$ if IAF $2-4 i=2$, if IAF is $5-7 ; i=3$ if IAF is $8-10$.

Normative isomorphism (NOR): Accounting professionalism and the extent of a professionalization process are a function of the degree of a formal education (academic and professional) environment. Considering that IFRS is a relatively complex area of accounting practice, the level of professional training and professionalization would be a relevant indicator of its adoption. Therefore, we derived a normative score (NOM) by averaging the rankings on the number of qualified accountants (QA) and the strength of professional accounting organization (PAO). The strength of PAO is ranked on an ordinal scale of 0-if a country doesn't have PAO, 1- if the country has PAO, 2- if the country has PAO which provides its professional qualification examination. Rankings based on number of qualified accountants (QA) were as 
follows Country $i$ is ranked 0 if $\mathrm{QA}<35^{\text {th }}$ percentile; $i=1$ if $\mathrm{QA}>35^{\text {th }}<75^{\text {th }} ; i=2$, if $\mathrm{QA}>75^{\text {th }}$ $<100^{\text {th }}$

Each of the three scores (COC, MIM, NOR) was scaled to 0-1 using this formula; scaled variable $=($ variable minus minimum $) /($ Maximum - minimum $)$.

Control variables: Based on prior studies, such as Boolaky and Sooborayen (2017), Ben Othman and Kossentini (2015), Judge et al. (2010) and Zeghal and Mhedhbi (2006) we control for economic growth with GDP growth rate (GR), trade openness with import penetration (IMPT), stock market development with market capitalization (MKC). We also controlled for the prevalence of foreign ownership (FOO) and colonialization (COL). Refer to Table 1.0 for the measurement of these variables.

\subsection{Empirical approach}

Since our dependent variable (IFRS-AD) is binary and can be extended to an ordinal scale, it is more appropriate to use logit and ordered logit models respectively ${ }^{2}$. To fit the logit model, we define IFRS adoption (IFRS-AD) as a binary variable of 0 and 1 to estimate. Next, we extend binary coding to an ordinal scale of $0-3$, to apply an ordered logit regression model.

We use our first equation (EQ1) to establish the association between the individual sources of institutional pressure and the adoption of IFRS.

$$
\begin{aligned}
& \text { Zitlog } \frac{\boldsymbol{p}(\text { IFRS_ADit }=\boldsymbol{\pi})}{\mathbf{1}-\boldsymbol{\pi}}=\alpha_{0}+\beta_{1} T C C+\beta_{2} R O S C+\beta_{4} I A F+\beta_{3} I F A C+\beta_{5} P A O+\beta_{6} N Q A+\beta_{7} C O L+\beta_{8} I M P T
\end{aligned}
$$

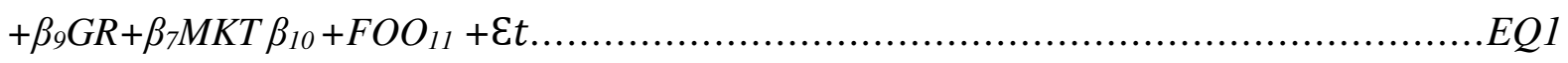

\footnotetext{
${ }^{2}$ Following from prior studies (Boolaky \& Soobaroyen, 2017; Ben Othman and Kossentini, 2015; Judge et al., 2010; Ramanna and Sletton, 2014) we also run ordinary least square models and the un-tabulated results are similar to the logit and ordered logit ones.
} 
Since institutional pressures flow from different sources, we run the second equation EQ2 where the individual source of pressure has been combined as a single score.

Zitlog $\frac{\boldsymbol{p}(\text { IFRS_ADit }=\boldsymbol{\pi})}{\boldsymbol{1}-\boldsymbol{\pi}}=\alpha_{0}+\beta_{1} C O V+\beta_{2} M I M+\beta_{4} N O R+\beta_{3} C O L+\beta_{5} I M P T+\beta_{6} G R+\beta_{7} M K T+\beta_{8} F O O$ $+\varepsilon t$ $E Q 2$

See Table 1.0 for variable description.

Insert Table 1.0. Variable description and sources of data and expected signs.

\subsection{Results and Discussions.}

\subsection{Descriptive statistics.}

The descriptive statistics on the variables are reported in Table 2 (categorical variables) and 3 (continuous). From Table 2, and as of 2015, only 18 African countries have mandated IFRS for all listed and large companies, while 25 countries have not committed to the use of IFRS. Six countries only require some companies to use IFRS and only 5 countries allow voluntary adoption of IFRS. Most of the IFRS-adopted countries are former British colonies, whereas the bulk of the non-IFRS counties are former French colonies. There are Report on Observance of Standards and Codes - Accounting and Auditing (ROSC) reports on 35 African countries. Of these reports, 12 countries were recommended to improve their own local standards, whereas 22 countries were recommended to adopt IFRS and one country was recommended to improve their existing standards in line with IFRS. Hence, it is somewhat consistent that 18 African countries have mandated IFRS, as of 2015.

A review of Professional Accounting Organisation (PAO) indicates that out of the 54 countries, 42 have a recognized PAO. However, only 13 of them organized their professional qualification examinations. There was an average of 3,475 accountants per country (Table 3), 
with a high standard deviation of 12,237 , minimum of 10 and a maximum of 67,890 , shows that some countries do have a significant shortage of accountants. Even in countries such as South Africa, Nigeria, and Ghana, which do have a relatively high number of accountants, the numbers on a per capita basis are still insufficient to meet accounting needs. As of 2015,22 African countries were full members of International Federation of Accountants (IFAC), with South Africa having the longest membership of 38 years. Finally, and although global accounting firms operate in a large number of countries worldwide, some of the top 10 global accounting firms do not operate in some African countries (e.g. Eritrea, Sudan)

Insert Table 2.0 Descriptive statistics of categorical variables.

Insert Table 3.0. Descriptive statistics of continuous variables.

We present the Person Pairwise correlation results in Table 4. All the variables of interest have a significant positive association with IFRS adoption status. The correlation among the variables is less than 0.80, thus not signaling multi-collinearity issues (Field, 2000; Tabachnick \& Fidell, 2007).

\section{Insert Table 4. Pairwise correlation between variables.}

\subsection{Country-level regression results.}

Table 5.0 reports the results for the logit and ordered logit regression estimates, hence testing the three hypotheses on the different institutional pressures associated with IFRS adoption. In M1 we explore the relationship between the individual sources of institutional pressures and a country's IFRS adoption decision. M2 provides the results for EQ2 whereby the different types of isomorphism are proxy by a score constructed from the individual sources of institutional pressures.

The results in M1 show that the different sources of institutional pressures are significant in their association with a country's IFRS adoption status except for the level of total 
commitment (TCC). Specifically, the coefficient of 0.446 at $1 \%$ significant for ROSC indicates that countries that received a recommendation from the IMF and World Bank to adopt IFRS are more likely to adopt IFRS than other countries. It, therefore, includes those countries that are engaging towards IFRS adoption as a result of a coercive pressure implied in the ROSC report. We also report a non-significant relationship between TCC and IFRS adoption. This can be interpreted by the point that a direct link between grants/loan and conditionality (such as adopting better governance and accountability regimes) have become less prevalent in WB/IMF policies (Hopper et al., 2017) given the emphasis of the financial support aimed directly at key issues such as poverty reduction, health, and education. Instead the emphasis of international institutions, including by WB and IMF, seem to be focused on developing and strengthening a global regime of economic, financial and governance standards, via the use of ROSC reports/assessments as a form of 'disciplining' mechanism (Chua and Taylor, 2008).

Although TCC is not significant in its own right, the COC coefficient, which represents the combined sources of external pressure, does support our first hypothesis that coercive pressures are significantly associated with IFRS adoption. In econometric terms, the coefficient of 1.934 for COC suggests that one standard deviation increase in the score of coercive pressure leads to a 0.6114 increase in the likelihood of a country's adoption of IFRS $(1.934 * 0.3147)$.

Regarding mimetic pressure, the coefficient of both variables of interest 0.551 (IAF) and 0.030 (IFAC) are statistically significant determinants of IFRS adoption at a p-value of $<0.01$. The results from the mimetic score (MIM) in M2 show that combined pressure from both IAF and IFAC is positive and significantly associated with IFRS adoption. Specifically, in economic terms, the coefficient of 2.557 at $1 \%$ significant level on MIM suggests that one standard deviation increase in mimetic pressure increases the likelihood of a country adopting IFRS by $0.8765(2.557 * 0.3428)$. These results support our hypothesis that African countries are more likely to engage with IFRS and international best practices as a result of a motivation to mimic 
practices endorsed, and implemented, by the transnational accounting agencies and firms, namely IFAC and global audit firms. The results suggest that countries that host more IAF are more likely to adopt IFRS because of the IAF's ability (expertise and resources) to engage at a practical level with policymakers, civil society and industry leaders on the benefits of applying international standards. Opinion leaders within these sectors (e.g. politicians, company directors, regulators, investor associations, chamber of commerce) can be sensitized on the logic of relying on off-the-shelf, socially acceptable and legitimate practices, thereby influencing relevant government authorities to consider mandating IFRS. The status of IAF, particularly in their role as auditors or offering professional services to listed companies, ensures that often their message is taken authoritatively. In a similar vein, IFAC's active engagement with its regular statement of membership obligations (SMO) process has established a regular and transparent benchmark on the status of all IFAC member organizations when it comes to the adoption of standards and norms recommended by IFAC and/or other transnational institutions. Therefore, the longer a country has been an IFAC member and is therefore cognisant of the norms of its membership, the more likely it will be influenced to promote the adoption of IFRS (relative to new entrants).

The results on the strength of professional accounting organization (PAO) and number of qualified accountants (QA) as a source of normative pressure support our third hypothesis. The positive and significant coefficient of PAO (0.908 @ 1\%) and QA (0.071 @ 1\%) indicates that the level of accounting professionalism and professionalization play a key role in a country's IFRS adoption decision. This is also evidenced in the positive significant coefficient of the normative score $(\mathrm{NOR}=2.252 @ 1 \%)$. To put it in an econometric perspective, one standard deviation increase in NOR leads to 0.77198 likelihood of a country adopting IFRS. Put differently the probability of a country adopting IFRS increases with the level of accounting professionalism in terms of the number of accountants and strength of the local accounting 
organization. Our findings indicate that PAO that provides regular training to members have continuous engagement with members and hence is more able to influence the profession and opinion in relation to IFRS.

To assess the robustness of our inferences with respect to the association between the extent of IFRS adoption and the hypothesized institutional pressures, we estimate both EQ1 and EQ2 using ordered logit regression. The dependent variable IFRS_AD is measured on an ordinal scale of 0-3. The results are present in M3 and M4 of Table 5. Overall, these results are not qualitatively different from that of the logit regression in M1 and M2. Hence, we reach the same inferences as those discussed on M1 and M2 from Table 5.

Most control variables revealed expected signs in predicting a country's IFRS adoption status. The coefficient of colonial history $(\mathrm{COL}=4.334)$ is positive and significant at $5 \%$ or less in all the models. Thus, ex-British colonies have a higher propensity to adopt IFRS compared to other countries in Africa (predominantly those previously colonized by France). The prevalence of foreign ownership is not deemed significant. One possible inference is that most foreign companies tend to report according to their home country's standards, which might not be IFRS. For instance, Canadian companies in Namibia report per Canadian GAAP (e.g., B2Gold, Merencia), Australian companies report as per Australian GAAP (e.g., Bannerman) and U. S. companies report per US GAAP (e.g., Anglo-American company).

Insert Table 5. Country-level regression results.

\subsection{Comparison with prior studies.}

In this section, we elaborate on how our study generates unique evidence on Africa as compared to the two prominent studies on IFRS adoption, namely by Judge et al. (2010) and 
Ben Othman and Kossentini (2015), which both included African countries in their dataset. To ensure an accurate comparison to these prior studies, we distinctively reconstructed the data used in those studies with a focus on African countries. Accordingly, the variables and period used in the comparative analysis are as similar as possible to data used in their respective original studies. Appendix B provides an extract describing variables used and reported by Judge et al. (2010) and Ben Othman and Kossentini (2015). It has to be noted that the analysis by Judge et al. (2010) was cross-sectional while Ben Othman and Kossentini (2015) used a pooled-regression approach. We also collected data on our variables: recommendations from $R O S C$, the number of international audit firms-IAF and the strength of professional accounting organization- $-P A O$ for the same period as covered by these studies.

The results are presented in Table 6 . Models 5-7 contain results of cross-sectional data using 2008 as the adoption year and averages as in Judge et al. (2010). M5 contains results using our variables, whereas M6 contains the variables of Judge et al (2010). M7 contains results using our variables and that of Judge et al. (2010). Whereas all our variables (COC, MIM, and NOR) in M5 are significant at 1\% and 5\%, none of the Judge et al. (2010) variables in M6 are significant except for foreign aid (FORAID) - which is significant at 5\% but negatively associated to IFRS adoption. M7 confirms the significant power of our variables as compared with Judge et al. 2010 in a single regression equation (Pseudo R2 of M7;0.4965>M6;0.1442). Arguably, therefore, countries at different levels of development (in our case, from the African continent) exhibit different characteristics and differences in terms of the circuits and source of isomorphic pressures. Hence, the neo-institutional theory-inspired findings drawn from a mix of developed and developing countries are not easily transposed to the African context. For instance, most developed countries, such as Australia, Canada, and the United Kingdom, have a high level of secondary school enrolment and low import penetration compared with most African countries, which have low secondary school enrolment but high 
import penetration. Furthermore, developed countries tend to be donors of foreign aid while Africa is a net recipient of foreign aid. In effect, the sources of isomorphic pressures outlined by Judge et al. (2010) are at extreme opposite ends for the sampled countries.

Models 8-10 of Table 6 contain results of pool-data data from 2005-2010. M8 contains results using our variables and M9 the variables used by Ben Othman and Kossentini (2015). M9 contains results using our variables and that of Ben Othman and Kossentini (2015) in a single regression.

We found that all our variables COC, MIM and NOR in M8 are significant at 1\% and 5\%, with only the mimetic variable (BIGTRFF) by Ben Othman and Kossentini (2015) being significant at $10 \%$. Apart from the differences in the significance levels and direction of the coefficients, our variables provide high explanatory power than that of prior studies as evidence in the Pseudo $\mathrm{R}^{2}$. The Pseudo $\mathrm{R}^{2}$ of M8 is $56 \%(0.336-0.215)$ and hence higher than M9, and this even applies to the M10 single regression of M10. Overall our comparative analyses in Table 6 showcase how our current study reveals institutional variables that are relevant and distinctive to the African context, which have been largely downplayed or ignored when relying on cross-continental/global research designs. In other words, our study provides a key contribution in providing empirical evidence of the specificity of neo-institutional variables and circuits driving IFRS adoption (or not) in Africa.

Insert Table 6.0 Comparison with prior studies (using logit regression where IFRS 0 or 1

\subsection{Firm-level regression results ${ }^{3}$.}

In this section, and as part of underpinning the robustness of our main results, we also investigate the institutional pressures of voluntary IFRS adoption by a sample of firms in

\footnotetext{
${ }^{3}$ We acknowledge this useful suggestion by one of the reviewers to include firm-level analyses as a robustness test.
} 
African countries. Although there are few studies, such as Bassemir (2018), Dumontier and Raffournier (1998), Francis et al. (2007), and Tarca (2004) on firm-level determinants, they focused on financial and economic factors and not on institutional pressures. Bassemir (2018) found that private German firms using IFRS are characterized by high growth opportunities, high international sales, high leverage, and high equity ownership. However, only a fraction of this sample relied on IFRS, implying that private firms do not expect a net gain from adopting IFRS. As most of the voluntary adopters are not listed companies, they are not expected to gain any net financial benefits from IFRS (Bassemir 2018). Hence, it would be fair to argue that their adoption would be driven by non-financial factors.

We, therefore, operationalized sources of institutional pressure at the firm level using corporate governance structures as follows: Ownership type (OWT) as a proxy variable for coercive pressure. Francis et al. (2007) claimed that foreign-owned companies face further information asymmetry problems because it is costly for foreigners to get more information about the company relative to local investors. Consequently, foreign investors are likely to exert external pressures for companies to adopt global standards that will reduce information asymmetry. Also, if foreign investors provide much of the capital, they will tend to bring in their home countries' practices into the company. In this case, OWT is measured as a dummy variable with $1=$ if the nationality of the majority owner of the firm is different from the place of domicile of the firm and 0 , otherwise.

Although the Big Four are not directly involved in the firm's decision-making process, they effectively can lobby firms to adopt global standards because of their experience (Bassemir, 2018) and the international network of IFRS experts. The Big Four firm also benefits from the firm's adoption of IFRS because they can draw from their global network of firms to undertake audits for multinational companies in Africa at a relatively low cost compared to other competing firms. Hence the Big Four (BIG4) do exert mimetic pressure on 
firms to adopt IFRS (Assenso et al., 2012). Big Four is a dummy variable of $1=$ if the company is audited by Big Four or 0, otherwise. Lastly, Chartered Accountants on Board $(C A B)$, in view of their professional affiliations, need to demonstrate high professional standards, inclusive of compliance with global standards. They are more hence likely to exert normative pressures on their firms to use IFRS. CAB is measured as the number of chartered accountants as a percentage of the total board size.

We also considered financial data such as growth in revenue $(R G)$, foreign sales $(F R)$, leverage $(L E V)$ and total assets $(T A A)$. Financial variables were selected based on findings of Bassemir (2018) and Francis et al. (2007), and they are limited to companies where data was available. We also included control variables such as company size with a board size (BS) and listing status (LS). We collected data from 220 African companies in countries that permit IFRS for the periods covering 2010-2015. The sample included both public and private companies. We admit that our measures of the institutional variables appear to be crude and hence, the results should be interpreted with caution.

The results of the multi-period logit regressions, as presented in Table 7. M11 and M12 examine the association of firm-level institutional pressures and IFRS adoption decisions. M11 is a random effect and M12 is fixed effect regression model. The coefficients of the mode of firm-level institutional pressures are significant at $1 \%$ except for $O W T$. The results show that companies voluntarily adopting IFRS are characterized by a high number of chartered accountants on board. These results are consistent with the notion that IFRS is driven by normative pressures. Due to their professional qualifications and affiliations, chartered accountants are more likely to influence their companies to adopt IFRS for improving quality reporting. The coefficient of $B I G 4$ is positive and significant as expected. Thus, firms that are audited by the Big Four are more likely to adopt IFRS indicating how the Big Four exerts some forms of memetic pressure on firms. 
Against expectations, the insignificant coefficient of $O W T$ implies that foreign-owned companies have a low propensity for adopting IFRS. The result is contrasted with Francis et al. (2007), who found a significant positive relationship between foreign ownership and IFRS adoption. We support our results with the argument that most of the foreign investors are from countries such as China, Canada, France, and the US, that are not necessarily enthusiastic about IFRS $^{4}$. More importantly, as majority shareholders, they hold key positions and thereby having access to internal information. Hence, there may be no need for requesting quality external reporting.

Next, in M13, we follow prior studies (Bassemir, 2018; Francis et al., 2007) to investigate the relationship between selected financial variables and the IFRS adoption decision of firms. The significant positive coefficient of both growth in revenue (RG) and leverage (LEV) implies that firms that require more financing have a greater propensity to adopt IFRS. This is consistent with the view that IFRS improve financing through a reduction in the cost of capital and information asymmetry (Barth et al., 2008; Mazzi et al., 2017). The insignificant coefficient of foreign sales $(F R)$ corroborates with the results on foreign ownership $(O W T)$. This is partly due to the fact most companies do not have high levels of foreign sales or few export trades to other African countries.

We combine both institutional and financial variables in M14. All the variables remain statistically significant and in the same direction as highlighted in M12 and M13. Furthermore, the Pseudo $\mathrm{R}^{2}$ for M14 (0.693) is higher than both M12 and M13, although the number of observations is small. In sum, our analyses indicate that in addition to financial variables,

\footnotetext{
${ }^{4}$ Relatedly, Nnadi and Soobaroyen (2015) find that, contrary to several worldwide studies, that paradoxically IFRS adoption is negatively associated to FDI levels in African countries. The authors inferred that foreign investors might be concerned with the costs of operating and transparency implications of investing in African IFRS-adopting countries.
} 
institutional pressures do directly influence companies to voluntarily adopt IFRS, especially if the company is private or unlisted.

\section{Insert Table 7. Regression results at the firm level.}

\subsection{CONCLUSION}

Existing literature on IFRS has claimed that most countries, and in particular developing countries, adopt IFRS due to its substantive economic benefits, adoption by neighboring countries, and external pressures from IFIs in terms of loans and grants. However, our contention that these findings are not self-evident for the African context and many extant studies have not directly examined Africa as a specific region. For example, common institutional variables, such as foreign aid, import penetration, secondary education, and market capitalisation (Judge et al., 2010; Koning et al., 2018; Ben Othman \& Kossentini, 2015; Ramman \& Sletton, 2014; Stainbank, 2014; Zeghal and Mhedhbi, 2006), have been considered as explanatory variables but we contend that some of the indicators are at the extreme lower end of the spectrum for African countries relative to other countries. Furthermore, during the past decade, more than $70 \%$ of countries worldwide have required the use of IFRS, and yet only $38 \%$ of African countries have mandated IFRS. This different trend in adoption suggests that there may be different dynamics that pertain to the African case and this has motivated our study to analyze the specific driving forces behind IFRS adoption (or not) on the continent. Informed by the neo-institutional perspective and distinctively therefore, we investigated the relevance of specific institutional pressures on IFRS adoption in Africa, controlling for other variables used in the literature.

Our findings reveal the relevance of coercive, mimetic, and normative, respectively in terms of the role of ROSC reports issued by the WB/IMF, the extent of the presence of 
international audit firms (IAF), the length of IFAC membership, the number of local professional accountants and the degree of professionalization of the local professional accounting organizations (PAO). The nature of these pressures on IFRS in Africa is different from what has been reported in mainstream quantitative IFRS-adoption studies and supports some of the country-level (qualitative) insights on IFRS adoption in developing and emerging countries (e.g. Hassan, 2008; Hassan et al., 2014; Nurunnabi, 2015). Furthermore, as a part of our robustness analyses, we were able to highlight the specificity of our neo-institutional proxies in the African context relative to prior studies (e.g. Judge et al., 2010; Ben Othman and Kossentini 2015).

Our findings provide a number of implications. Firstly, it chimes with Chua and Taylor's (2008) critical claims about the rapid 'rise and rise' of IFRS adoption and the relevance of the social and political dimensions behind the 'IFRS globalization' project, in contrast to the mainstream economic motivations and discourses of foreign investment and stock market development. Such motivations and discourses appear to be merely symbolic and deployed as a way to justify prompt and rapid adoption. From this perspective, there are however lingering questions as to the speed at which African countries might be expected to adopt IFRS and the extent of these countries' preparedness for adoption (assuming it is at all needed). Secondly, and from a policymaking perspective, the results do reveal the relevance of crucial circuits by which the case for adoption can be made. Our evidence also indicates the important role of local accountants and PAOs in IFRS adoption. Hence, transnational governance bodies, international financial institutions, and national governments need to first consider the need for robust and in-depth capacity building programs in accounting and enforcement expertise before proceeding towards IFRS adoption. One conjecture is that whilst IFRS adoption does appear to convey a strong legitimating signal for an African country and for its accounting community as a whole, the immediate benefits of such a rapid and 
unsupported adoption would most likely flow, almost exclusively, to a relatively small group of local IAF representatives and affiliate entities of IFRS-complying multinationals. This implies that relatively little benefit would come to the wider accounting profession and for the vast majority of local companies, which in turn may negatively impact on a substantive, longterm and in-depth national engagement with accounting standards.

\section{References}

Albu, N., Albu, C. N., Bunea, S., Calu, D. A., Girbina, M. (2011). A story about IAS/IFRS implementation in Romania: An institutional and structuration theory perspective. Journal of Accounting in Emerging Economies. 1 (1), 76-100.

Al-Akra, M, Ali, M.J \& Marashdeh, O. (2009). Development of accounting regulation in Jordan. The International Journal of Accounting. 44, 163-186.

Alon A. \& Dwyer, P. (2014). Early adoption of IFRS as a strategic response to transnational and local influences. The International Journal of Accounting 49(3), pp 348-370.

Assenso-Okofo, O., Ali, M.J. \& Ahmed, K. (2011). The development of accounting and reporting in Ghana. The International Journal of Accounting, 46(4), 459-480.

Archambault, J. J., \& Archambault, M. E. (2009). An analysis of social factors influencing the adoption of International Financial Reporting Standards. Journal for Global Business Advancement, 2 (1-2), 38-53.

Ball, R. (2006). International Financial Reporting Standards (IFRS): pros and cons for investors. Accounting \& Business Research 36 (sup1): 5-27.

Barth, M. E., Landsman, W. R., \& Lang, M. H. (2008). International accounting standards and accounting quality. Journal of accounting research, 46(3), 467-498. 
Bassemir, M. (2018). Why do private firms adopt IFRS? Accounting and Business Research, 48(3), 237-263.

Ben Othman, B. \& Kossentini, A. (2015). A study of the institutional and economic determinants of IFRS adoption in emerging economies https://business.illinois.edu/drupalfiles/accountancy/files/Kossentini.pdf

Birkett, W.P. and Evans, E., 2005. Theorising professionalization: a model for organising and understanding histories of the professionalising activities of occupational associations of accountants. Accounting History, 10(1), pp.99-127.

Boolaky, P., Ghattas, P., Marnet, O. \& Soobaroyen, T. (2020). International Standards on Auditing (ISAs): Conflicting Influences on Implementation. In Weetman P. and Tsalavoutas, I. (Eds). The Routledge Companion to Accounting in Emerging Economies. Routledge.

Boolaky, P. \& Soobaroyen, T. (2017). Adoption of International Standards on Auditing (ISA): Do Institutional Factors Matter? International Journal of Auditing, 21(1), 59-81

Boolaky, P.K. (2012). Accounting development and international financial reporting standards in small island economies: The case of Mauritius between 1960 and 2008. Journal of Accounting in Emerging Economies, 2(1), 4-29.

Bova, F., \& Pereira, R. (2012). The Determinants and Consequences of Heterogeneous IFRS Compliance Levels Following Mandatory IFRS Adoption: Evidence from a Developing Country. Journal of International Accounting Research, 11(1), 83-111

Chua, W.F. \& Taylor, S.L., (2008). The rise and rise of IFRS: An examination of IFRS diffusion. Journal of accounting and public policy, 27(6), pp.462-473. 
Clements, C.E., Neill, J.D. and Stovall, O.S., 2009. The impact of cultural differences on the convergence of international accounting codes of ethics. Journal of Business Ethics, 90(3), pp.383-391.

Degos, J.-G., Levant, Y. and Touron, P. (2018) 'The history of accounting standards in Frenchspeaking African countries since independence', Accounting Auditing and Accountability Journal (forthcoming).

DiMaggio, P. \& Powell, W. W. (1991). The new institutionalism in organizational analysis. Chicago: University of Chicago Press.

DiMaggio, P. \& Powell, W. (1983). The Iron Cage Revisited: Institutional Isomorphism and Collective Rationality in Organizational Fields. American Sociological Review 48(2), 147-160

Ding, Y., Jeanjean, T., \& Stolwy, H. (2005). Why do national GAAP differ from IAS? The role of culture. The International Journal of Accounting, 40: 325-350.

Dumontier, P. and Raffournier, B., 1998. Why firms comply voluntarily with IAS: an empirical analysis with Swiss data. Journal of International Financial Management and Accounting, 9 (3), 216-245.

Efobi, U. R. (2015). IFRS adoption and the environment: Is Africa closing her eyes to something? Advances in Sustainability and Environmental Justice. 17 169-195.

Elad, C. (2015). The Development of Accounting in the Franc Zone Countries in Africa. The International Journal of Accounting, 50(1), 75-100.

Field, A. (2000). Discovering Statistics Using SPSS for Windows, Thousand Oaks, CA: Sage Publications. 
Francis, J. R., Khurana, I. K., Martin, X. and Pereira, R., (2008). The role of firm-specific incentives and country factors in explaining voluntary IAS adoptions: evidence from private firms. European Accounting Review, 17 (2), 331-360

Guler, I., Guillen, M., \& Macpherson, J. (2002). Global competition, institutions, and the diffusion of organizational practices: The international spread of ISO 9000 quality certificates. Administrative Science Quarterly, 47(2): 207-232.

Hassan, E. A., Rankin, M., \& Lu, W. (2014). The Development of Accounting and Reporting in Iraq and the IFRS Decision: An Institutional Perspective. The International Journal of Accounting,49, 371-390.

Hassan. M (2008) "The development of accounting regulations in Egypt: Legitimating the International Accounting Standards", Managerial Auditing Journal, 23 (5), pp.467-484.

Hegarty, J., Gielen, F. \& Barros, H. (2004). Implementation of International Accounting and Auditing Standards: Lessons learned from the World Bank's Accounting and Auditing ROSC Program. Washington: World Bank. https://www.worldbank.org/ifa/LessonsLearned ROSC AA.pdf

Hope, O., J. Jin \& T. Kang. (2006). Empirical evidence on jurisdictions that adopt IFRS. Journal of International Accounting Research 5, 1-20.

Hopper, T., Lassou, P.J.C., and Soobaroyen, T. (2017). Globalisation, accounting and developing countries. Critical Perspectives on Accounting, 43, 125-148.

Humphrey, C., Loft, A. and Woods, M., (2009). The global audit profession and the international financial architecture: Understanding regulatory relationships at a time of financial crisis. Accounting, organizations and society, 34(6-7), pp.810-825.

Iasplus.com. https://www.iasplus.com/en/resources/ifrs-topics/adoption-of-ifrs 
IMF (2003). The IMF and good governance: A factsheet. Washington DC: International Monetary Fund.

Joshi, P. L., Bremser, W. G., Al-Ajmi, J., (2008). Perceptions of accounting professionals in the adoption and implementation of a single set of global accounting standards: Evidence from Bahrain. Advances in Accounting, incorporating Advances in International Accounting. 24, 4148.

IFRS Foundation (2016). Annual Report 2016. https://www.ifrs.org/-/media/feature/aboutus/funding/annual-report-2016.pdf Access on December 2017.

Judge, W., Li, S. \& Pinsker, R. (2010). National adoption of international accounting standards: An international perspective. Corporate Governance: An International Review, 18 (3), 161174.

Koning, M., Mertens, G. \& Roosenboom, P. (2018). Drivers of institutional change around the world: The case of IFRS. Journal of International Business Studies 49, 249-271.

Larson, M. S. (1977). The rise of professionalism. Berkeley: University of California Press.

Lassou, PJC. and Hopper, T. (2016). Government Accounting Reform in an ex-French African Colony: The Political Economy of Neo-colonialism. Critical Perspectives on Accounting, 36, 39-57.

Lounsbury, M. \& Zhao Y. (2013). Neo-institutional theory, in Griffin, R. (Ed.): Oxford Bibliographies in Management. Oxford University Press, New York.

Mazzi, F., Andre, P., Dionysiou, D. \& Tsalavoutas, I. (2017). Compliance with goodwillrelated mandatory disclosure requirements and the cost of equity capital. Accounting and Business Research, 47(3), 268-312. 
McPeak, D., Pincus, K.V. and Sundem, G.L., (2012). The international accounting education standards board: influencing global accounting education. Issues in Accounting Education, 27(3), pp.743-750.

Mir, M. \& Rahman, S. (2005). The adoption of international accounting standards in Bangladesh. Accounting Auditing and Accountability Journal., 18 (6). 816-841.

Mueller, G., Gernon, H., \& Meek, G. (1994). Accounting: An international perspective. Burr Ridge, IL.

Muniandy, B., Ali, M. J., (2012). Development of financial reporting environment in Malaysia. Research in Accounting Regulation. 24. 115-125.

Nurunnabi, M., (2015). The impact of cultural factors on the implementation of global accounting standards (IFRS) in a developing country. Advances in Accounting, 31(1), pp.136149.

Nnadi, M. \& Soobaroyen, T. (2015). International financial reporting standards and foreign direct investment: The case of Africa. Advances in Accounting, 31 (2), pp 228-238.

Nnadi, M. (2012). International Financial Reporting Standards (IFRS) adoption in Africa: The influence of Anglo neo-colonialism. Cardiff University Working Paper

Perumpal, Sharini E., Evans, Mark., Sanjay, Agarwal and Amenkhienan, Felix. (2009). The evolution of Indian Accounting Standards: Its History and Current Status With Regard to International Financial Reporting Standards. Advances in Accounting, 25 (1):106-111.

Phuong, N. \& Nguyen, T. D., (2012). International harmonization and national particularities of accounting; Recent accounting development in Vietnam. Journal of Accounting and Organizational Change. 8(3), 431-451. 
PWC (2017). 2017 African Capital Markets Watch. https://www.pwc.co.za/en/assets/pdf/africancapital-markets-2018.pdf

Rahaman, A.S. (2010). Critical accounting research in Africa: whence and whither. Critical Perspectives on Accounting, 21(5), 420-7.

Ramanna, K., \& Sletten, E. (2014). Network Effects in Countries' Adoption of IFRS. Accounting Review, 89(4), 1517-1543.

Ritsumeikan, L. (2011). An Institutional Perspective on International Financial Reporting Standards Adoption in Developing Countries. Academy of Accounting and Financial Studies Journal, Volume 15, Special Issue, Number 2, 61-71.

Rodrigues, L., \& Craig, R., (2007). Assessing international accounting harmonization using Hegelian dialectic, isomorphism and Foucault. Critical Perspectives on Accounting, 18(6), $739-757$

Schneper, W. \& Guillen, M. (2004). Stakeholder rights and corporate governance: A crossnational study of hostile takeovers. Administrative Science Quarterly, 49: 263-295.

Scott, R. (2001). Institutions and organizations, 2nd edn. Thousand Oaks, CA: Sage.

Scott, R. (1987). The adolescence of institutional theory. Administrative Science Quarterly, 32(4) 493-511.

Sian, S., (2006). Inclusion, exclusion and control: The case of the Kenyan accounting professionalization project. Accounting, Organizations and Society, 31(3), pp.295-322.

Stainbank L.J., (2014). Factors Influencing the Adoption of International Financial Reporting Standards by African Countries. South African Journal of Accounting Research, 28:1, 79-95 
Street, D. (2002). GAAP 2001 - benchmarking national accounting standards against IAS: Summary of results. Journal of International Accounting, Auditing \& Taxation, 11, 77-90.

Tabachnick, B. G. \& Fidell, L.S. (2007). Using multivariate statistics. Boston, MA: Pearson/Allyn \& Bacon.

Tarca, A, (2004), International convergence of accounting practices: Choosing between IAS and US GAAP, Journal of International Financial Management \& Accounting 15, 60-91

Touron, P. (2005). The adoption of US GAAP by French firms before the creation of the International Accounting Standard Committee: An institutional explanation. Critical Perspectives on Accounting, 16: 851-873.

Tyrrall, D., Woodward, D. and Rakhimbekova, A. (2007), "The relevance of international financial reporting standards to a developing country: evidence from Kazakhstan. The International Journal of Accounting, 42 (1), 82-110.

Wyatt, A. R. (1997). International Accounting Standards and Organizations: Quo Vadis? In F. D. Choi, International Accounting and Finance Handbook (pp. 10.1-10.22). New York: John Wiley \& Sons.

World Bank (2005), Conditionality Revisited: Concepts, Experiences and Lessons Learned, Washington DC.

World Bank (2002-2015). Report on the observance of standards and codes (ROSC): Accounting and auditing — All African countries. (Washington DC).

World Economic Forum (2016) This African trade deal could improve lives across the whole continent. https://www.weforum.org/agenda/2016/05/this-african-trade-deal-could-improve-lives-across-the$\underline{\text { whole-continent }}$ 
Zarzeski, T. (1996). Spontaneous harmonization effects of culture and market forces on accounting disclosure practices. Accounting Horizons, 10(1), 18-37.

Zeghal D. \& Mhedhbi K. (2006). An analysis of the factors affecting the adoption of

International accounting standards by developing countries, The International Journal of Accounting, 41(4): 373-386

Zori, S. (2015). The State of IFRS in Africa: Is IFRS in Disarray? www.governancexborders.com To Adopt or Not to Adopt? The Transnational Adoption of International Financial Reporting Standards (IFRS) in Africa, PhD Thesis Universität zu Köln kups.ub.unikoeln.de/.../Solomon_Zori_Dissertation_2015_To_Adopt_Or_... 


\section{Tables}

\section{Table 1.0 Variable description and sources of data.}

\begin{tabular}{|c|c|c|c|c|c|}
\hline Determinants & Variable. & Acronym & Description & Data Source & Exp. Sign \\
\hline Dependent & $\begin{array}{l}\text { Country IFRS } \\
\text { adoption } \\
\text { status. }\end{array}$ & IFRS & $\begin{array}{l}\text { A categorical variable measuring the level of IFRS } \\
\text { adoption in a country. } \\
0 \text { - not permitted, } 1 \text { - permitted; } 2 \text { - required by some } \\
\text { companies; } 3 \text { - required by all companies. }\end{array}$ & $\begin{array}{l}\text { iasplus.com, } \\
\text { IFRS.org, } \\
\text { PWC, IFAC } \\
\text { ROSC }\end{array}$ & \\
\hline \multirow[t]{3}{*}{ Coercive } & Coercive score & $\mathrm{COC}$ & The average of TCC and ROSC rankings scaled to $0-1$ & & Positive \\
\hline & $\begin{array}{l}\text { Total } \\
\text { Commitments. }\end{array}$ & TCC & $\begin{array}{l}\text { Total commitments disbursed by WB and IMF group to } \\
\text { a country. Country } i \text { is ranked } 0 \text { if TCC }<25^{\text {th }} \text { percentile; } \\
i=1 \text { if } \mathrm{TCC}>25^{\text {th }}<50^{\text {th }} ; i=2 \text {, if TCC }>50^{\text {th }}<75^{\text {th }} ; i=3 \\
\text { if } T C C>75^{\text {th }}<100^{\text {th }} \text {. }\end{array}$ & $\begin{array}{l}\text { OECD } \\
\text { statistics }\end{array}$ & \\
\hline & $\begin{array}{l}\text { Report on the } \\
\text { Observance of } \\
\text { Standards and } \\
\text { Codes; } \\
\text { Accounting } \\
\text { and Auditing. }\end{array}$ & ROSC & $\begin{array}{l}\text { The IMF \& World Bank ROSC (AA) issued on the } \\
\text { country. An ordinal variable of } 0 \text { - no ROSC on the } \\
\text { country, } 1 \text { - ROSC issued on the country; } 2 \text { - ROSC } \\
\text { recommended the development of accounting standard } \\
\text { based on IFRS; } 3 \text { - ROSC recommended the adoption of } \\
\text { IFRS. }\end{array}$ & ROSC website & \\
\hline \multirow[t]{3}{*}{ Mimetic } & Mimetic Score & MIM & The average of IAF and IFAC rankings scaled to $0-1$ & & Positive \\
\hline & $\begin{array}{l}\text { International } \\
\text { Audit Firms }\end{array}$ & IAF & $\begin{array}{l}\text { Number of the top } 10 \text { International Accounting Firms in } \\
\text { the country. Rankings based on international audit firms } \\
\text { were as follows country } \mathrm{i}=0 \text { if IAF is } 0-1 ; i=1 \text { if IAF } \\
2-4 i=2 \text {, if IAF is } 5-7 ; i=3 \text { if IAF is } 8-10 \text {. }\end{array}$ & $\begin{array}{l}\text { International } \\
\text { Accounting } \\
\text { Bulletin } 2017\end{array}$ & \\
\hline & $\begin{array}{l}\text { IFAC } \\
\text { Membership }\end{array}$ & IFAC & $\begin{array}{l}\text { Number of years a country has been a member of IFAC. } \\
\text { Up to } 2015 \text {. Country } i \text { is ranked } 0 \text { if IFAC }<25^{\text {th }} \\
\text { percentile; } i=1 \text { if IFAC }>25^{\text {th }}<50^{\text {th }} ; i=2 \text {, if IFAC }>50^{\text {th }} \\
<75^{\text {th }} ; i=3 \text { if } \text { IFAC }>75^{\text {th }}<100^{\text {th }}\end{array}$ & IFAC website & \\
\hline \multirow[t]{3}{*}{ Normative } & $\begin{array}{l}\text { Normative } \\
\text { Score }\end{array}$ & NOR & The average of QA and PAO rankings scaled to $0-1$ & & \multirow[t]{3}{*}{ Positive } \\
\hline & $\begin{array}{l}\text { Qualified } \\
\text { Accountants }\end{array}$ & QA & $\begin{array}{l}\text { Number of Qualified Accountants per listed companies. } \\
\text { Rankings based on number of qualified accountants } \\
\text { (QA) were as follows Country } i \text { is ranked } 0 \text { if QA }<35^{\text {th }} \\
\text { percentile; } i=1 \text { if QA }>35^{\text {th }}<75^{\text {th }} ; i=2 \text {, if QA }>75^{\text {th }} \\
<100^{\text {th }} \text {. }\end{array}$ & $\begin{array}{l}\text { Country PAO } \\
\text { websites, and } \\
\text { annual reports }\end{array}$ & \\
\hline & $\begin{array}{l}\text { Professional } \\
\text { Accountancy } \\
\text { Organisation. }\end{array}$ & PAO & $\begin{array}{l}\text { Measures the existence and strength of country PAO on } \\
\text { the scale of } 0-2 \text {, where } 0 \text {-no PAO; } 1 \text { - there is PAO but } \\
\text { does not organize its professional examination; } 2 \text { - PAO } \\
\text { that organize its professional examination. }\end{array}$ & $\begin{array}{l}\text { Country PAO } \\
\text { websites, } \\
\text { contacts and } \\
\text { annual reports }\end{array}$ & \\
\hline & & & & & \\
\hline
\end{tabular}




\begin{tabular}{|l|l|l|l|l|l|}
\hline $\begin{array}{l}\text { Control } \\
\text { variables }\end{array}$ & $\begin{array}{l}\text { Import } \\
\text { Penetration }\end{array}$ & IMPT & $\begin{array}{l}\text { The ratio of import value to commodities sold as a } \\
\text { proportion of the gross domestic product. }\end{array}$ & WDI \\
\hline & $\begin{array}{l}\text { GDP growth } \\
\text { rate }\end{array}$ & GR & Annual GDP growth rate. & WDI \\
\hline & $\begin{array}{l}\text { Market } \\
\text { capitalization }\end{array}$ & MKC & Market capitalization as a percentage of GDP & WDI & Positive \\
& $\begin{array}{l}\text { Foreign } \\
\text { Ownership }\end{array}$ & FOO & $\begin{array}{l}\text { Measures the prevalence of foreign ownership on a scale } \\
\text { of 1-7 }\end{array}$ & $\begin{array}{l}\text { World } \\
\text { Economic } \\
\text { Forum }\end{array}$ & Positive \\
\hline & Colonization & COL & $\begin{array}{l}\text { Proxy for the colonial history of the country. 1 for all } \\
\text { countries colonized by Britain and } 0 \text { for others. }\end{array}$ & $\begin{array}{l}\text { Multiple } \\
\text { sources }\end{array}$ \\
\hline
\end{tabular}


Table 2.0 Descriptive statistics of categorical variables

\begin{tabular}{|c|c|c|c|c|}
\hline Variable & Categories & Frequency & Mean & Standard Err \\
\hline & Non-Adopter (0) & 31 & & 0.0669 \\
\hline \multirow[t]{3}{*}{ IFRS01 } & Adopters (1) & 23 & 0.3889 & 0.0669 \\
\hline & Not permitted & 25 & & 0.0684 \\
\hline & Permitted & 6 & & 0.0487 \\
\hline \multirow[t]{3}{*}{ IFRS0123 } & Required Some & 5 & 1.2407 & 0.0359 \\
\hline & Required All & 18 & & 0.0637 \\
\hline & No ROSC issue & 19 & & 0.0655 \\
\hline \multirow[t]{4}{*}{ ROSC } & To improve & 12 & & 0.0571 \\
\hline & To develop IFRS & 1 & 1.4814 & 0.0185 \\
\hline & To adopt IFRS & 22 & & 0.0675 \\
\hline & No PAO & 12 & & 0.0571 \\
\hline \multirow[t]{2}{*}{ PAO } & PAO no Training & 29 & 1.0185 & 0.0684 \\
\hline & PAO \& Training & 13 & & 0.0587 \\
\hline
\end{tabular}

Notes: IFRS01 - binary coding where 0 - if a country has not adopted IFRS. 1 - if the country has adopted IFRS. IFRS0123 - order of $0,1,23$. ' 0 '= IFRS not permitted; ' 1 ' IFRS permitted; ' 2 '= IFRS required by some companies; ' 3 ' $=$ IFRS required by all companies. ROSC - Recommendations of ROSC (AA) reports. PAO - the strength of Professional Accounting Organisation 
Table 3. Descriptive statistics of continuous variables

\begin{tabular}{|c|c|c|c|c|c|}
\hline Variable & OBS & Mean & Std. Dev & Min. & Max \\
\hline$C O C$ & 270 & 1.490 & 0.944 & 0 & 3 \\
\hline MIM & 270 & 1.166 & 1.032 & 0 & 3 \\
\hline NOR & 270 & 0.962 & 0.685 & 0 & 2 \\
\hline$T C C$ & 270 & 3010.19 & 3173.866 & 30.75 & 13523.82 \\
\hline$I A F$ & 270 & 4 & 3 & 0 & 10 \\
\hline$I F A C$ & 270 & 9.6851 & 13.4302 & 0 & 38 \\
\hline$O A$ & 270 & 3,475 & 12,237 & 10 & 67,890 \\
\hline
\end{tabular}

Notes: COC - Coercive score on an ordinal scale of 0-3. MIM-Mimetic score on an ordinal scale of 0-3. NOR Normative score on an ordinal scale of 0-2. TCC - Total Commitments (in a million US\$). IAF- Number of the top 10 International Audit Firms. IFAC- IFAC membership. QA - Number of Qualified Accountants. IMPT Import Penetration. GR - GDP Growth Rate. 
Table 4. Pairwise correlation between variables.

\begin{tabular}{|c|c|c|c|c|c|c|c|c|c|c|}
\hline Variable & IFRS01 & IFRS0123 & TCC & ROSC & IAF & IFAC & QA & PAO & IMPT & GR \\
\hline IFRS01 & 1.00 & & & & & & & & & \\
\hline IFRS0123 & $0.95 * * *$ & 1.00 & & & & & & & & \\
\hline TCC & 0.16 & 0.22 & 1.00 & & & & & & & \\
\hline ROSC & $0.54 * * *$ & $0.55^{* * *}$ & $0.40 * * *$ & 1.00 & & & & & & \\
\hline IAF & $0.67 * * *$ & $0.69 * * *$ & $0.46 * * *$ & $0.54 * * *$ & 1.00 & & & & & \\
\hline IFAC & $0.56 * * *$ & $0.54 * * *$ & $0.39 * * *$ & $0.40 * * *$ & $0.58 * * *$ & 1.00 & & & & \\
\hline QA & $0.41 * *$ & $0.29 * *$ & 0.21 & $0.24 *$ & $0.43 * * * *$ & $0.55 * * *$ & 1.00 & & & \\
\hline PAO & $0.65 * * *$ & $0.64 * * *$ & $0.50 * * *$ & $0.59 * * *$ & $0.74 * * *$ & $0.68 * * *$ & $0.35^{* *}$ & 1.00 & & \\
\hline IMPT & -0.02 & -0.04 & $-0.47 * *$ & -0.14 & -0.0725 & -0.08 & -0.16 & -0.21 & 1.00 & \\
\hline GDR & $0.28 * *$ & $0.37 * * * *$ & $0.45^{* * *}$ & $0.40 * * *$ & $0.311^{* *}$ & $0.23 *$ & 0.04 & $0.34 * *$ & -0.05 & 1.00 \\
\hline $\mathrm{COL}$ & $0.657 * * *$ & $0.725 * * *$ & $0.469 * * *$ & $0.518 * * *$ & $0.405^{* * *}$ & -0.053 & -0.102 & 0.298 & 0.464 & 0.067 \\
\hline
\end{tabular}

Notes: Significant levels - $* * *=1 \%, * *=5 \%, *=10 \%$. 
Table 5. Country-level regression results.

\begin{tabular}{|c|c|c|c|c|c|}
\hline \multirow[b]{2}{*}{ Variables } & \multirow[b]{2}{*}{ Isomorph. } & \multicolumn{2}{|c|}{ Main results } & \multicolumn{2}{|c|}{ Robustness check } \\
\hline & & $\begin{array}{l}\text { Logit } \\
\text { (M1) }\end{array}$ & $\begin{array}{l}\text { Logit } \\
\text { (M2) }\end{array}$ & $\begin{array}{l}\text { Ordered } \\
\text { logit (M3) }\end{array}$ & $\begin{array}{c}\text { Ordered } \\
\text { logit (M4) }\end{array}$ \\
\hline TCC & Coercive & $\begin{array}{l}-0.003 \\
(-0.09)\end{array}$ & & $\begin{array}{l}-0.000 \\
(-0.52)\end{array}$ & \\
\hline ROSC & Coercive & $\begin{array}{l}0.446^{* * * *} \\
(6.60)\end{array}$ & & $\begin{array}{l}0.522 * * * \\
(3.95)\end{array}$ & \\
\hline IAF & Mimetic & $\begin{array}{l}0.551 * * * \\
(9.50)\end{array}$ & & $\begin{array}{l}0.552 * * \\
(2.13)\end{array}$ & \\
\hline IFAC & Mimetic & $\begin{array}{l}0.030 * * * \\
(3.08)\end{array}$ & & $\begin{array}{l}0.069 * * \\
(1.96)\end{array}$ & \\
\hline PAO & Normative & $\begin{array}{l}0.908 * * * \\
(4.46)\end{array}$ & & $\begin{array}{l}1.293^{* * *} \\
(2.29)\end{array}$ & \\
\hline QA & Normative & $\begin{array}{l}0.071 * * * \\
(3.32)\end{array}$ & & $\begin{array}{l}0.002 * * \\
(2.13)\end{array}$ & \\
\hline $\mathrm{COC}$ & Coercive & & $\begin{array}{l}1.934 * * * \\
(10.62)\end{array}$ & & $\begin{array}{l}2.662 * * * \\
(2.60)\end{array}$ \\
\hline MIM & Mimetic & & $\begin{array}{l}2.557 * * * \\
(7.59)\end{array}$ & & $\begin{array}{l}4.091 * * * \\
(3.31)\end{array}$ \\
\hline NORM & Normative & & $\begin{array}{l}2.252 * * * \\
(5.37)\end{array}$ & & $\begin{array}{l}1.028 * * \\
(2.25)\end{array}$ \\
\hline COL & & $\begin{array}{l}4.334 * * \\
(2.34)\end{array}$ & $\begin{array}{l}0.763 * * * \\
(8.65)\end{array}$ & $\begin{array}{l}3.987 * * * \\
(3.86)\end{array}$ & $\begin{array}{l}0.324 * * * \\
(4.13)\end{array}$ \\
\hline IMPT & & $\begin{array}{l}0.064^{*} \\
(1.74)\end{array}$ & $\begin{array}{l}0.045^{*} \\
(1.64)\end{array}$ & $\begin{array}{l}0.031 * \\
(1.81)\end{array}$ & $\begin{array}{l}0.025 \\
(1.48)\end{array}$ \\
\hline GR & & $\begin{array}{l}0.147^{*} \\
(1.90)\end{array}$ & $\begin{array}{l}0.076 \\
(1.12)\end{array}$ & $\begin{array}{l}0.057 \\
(0.21)\end{array}$ & $\begin{array}{l}0.056^{*} \\
(1.73)\end{array}$ \\
\hline MKT & & $\begin{array}{l}0.053 * * \\
(2.08)\end{array}$ & $\begin{array}{l}0.002 * \\
(1.85)\end{array}$ & $\begin{array}{l}0.121 * * \\
(2.13)\end{array}$ & $\begin{array}{l}0.002 * * \\
(2.20)\end{array}$ \\
\hline FOO & & $\begin{array}{l}0.035 \\
(0.21)\end{array}$ & $\begin{array}{l}0.090 \\
(1.07)\end{array}$ & $\begin{array}{l}0.025 \\
(1.14)\end{array}$ & $\begin{array}{l}0.420 \\
(1.70)\end{array}$ \\
\hline Constant & & $\begin{array}{l}-9.076 * * * \\
(-3.51)\end{array}$ & $\begin{array}{l}-11.45 * * * \\
(-5.13)\end{array}$ & & \\
\hline Year fixed effect & & Yes & Yes & Yes & Yes \\
\hline Number of obs. & & 270 & 270 & 270 & 270 \\
\hline $\begin{array}{l}\text { Number } \\
\text { countries }\end{array}$ & & 54 & 54 & 54 & 54 \\
\hline Pseudo $\mathbf{R}^{2}$ & & 0.6870 & 0.4158 & 0.4705 & 0.2562 \\
\hline
\end{tabular}

Notes: This table reports estimates of multi-period, logit and ordered logit models with time-varying covariates for the likelihood of adopting IFRS at country level for the full sample. Model 1 is logit regression and Model 2 is ordered logit regression for the main results. Models 3 and 4 are is logit regression and Model 2 is ordered logit regression respectively for robustness check where COC, MIM, and NOR are scaled to $0-1$. The models include all observations available from 2010 to 2015. Explanatory variables are measured contemporaneously with IFRS years, i.e. they are not lagged. For variable definitions, see Table 1. Z-statistics are presented in parentheses. Stars indicate statistical significance: $* \mathrm{p}<.1, * * \mathrm{p}<.05, * * * \mathrm{p}<.01$. 
Table 6.0 Comparison with prior studies (using logit regression where IFRS 0 or 1)

\begin{tabular}{|c|c|c|c|c|c|c|c|}
\hline \multirow[b]{2}{*}{ Variables } & \multirow[b]{2}{*}{ Isomorph. } & \multicolumn{3}{|c|}{ Judge et al. 2010 study } & \multicolumn{3}{|c|}{ Kossentini \&Othman } \\
\hline & & M5 & M6 & M7 & M8 & M9 & M10 \\
\hline $\mathrm{COC}$ & Coercive & $\begin{array}{l}0.691 * * \\
(2.40)\end{array}$ & & $\begin{array}{l}0.767 * * \\
(2.05)\end{array}$ & $\begin{array}{l}0.071 * * \\
(2.17)\end{array}$ & & $\begin{array}{l}0.650 * * * \\
(4.47)\end{array}$ \\
\hline MIM & Mimetic & $\begin{array}{l}1.19 * * * \\
(3.15)\end{array}$ & & $\begin{array}{l}0.467 * * * \\
(3.29)\end{array}$ & $\begin{array}{l}0.920 * * \\
(2.20)\end{array}$ & & $\begin{array}{l}0.705^{* * *} \\
(3.53)\end{array}$ \\
\hline NORM & Normative & $\begin{array}{l}0.128 * * \\
* \\
(4.19)\end{array}$ & & $\begin{array}{l}0.505 * * \\
(2.55)\end{array}$ & $\begin{array}{l}1.348 * * \\
(2.02)\end{array}$ & & $\begin{array}{l}0.955^{* * * *} \\
(3.21)\end{array}$ \\
\hline \multicolumn{8}{|c|}{ Judge et al. (2010) } \\
\hline FORAID & Coercive & & $\begin{array}{l}-0.028 * * \\
(2.01)\end{array}$ & $\begin{array}{l}-0.018 * * \\
(2.28)\end{array}$ & & & \\
\hline IMPT & Mimetic & & $\begin{array}{l}0.001 \\
(0.45)\end{array}$ & $\begin{array}{l}0.050 \\
(1.53)\end{array}$ & & & \\
\hline SECON & Normative & & $\begin{array}{l}0.055 \\
(1.09)\end{array}$ & $\begin{array}{l}0.033 \\
(0.90)\end{array}$ & & & \\
\hline \multicolumn{8}{|c|}{$\begin{array}{l}\text { Kossentini \& Othman } \\
2015\end{array}$} \\
\hline FAROSC & Coercive & & & & & $\begin{array}{l}0.022 \\
(0.76)\end{array}$ & $\begin{array}{l}0.022 \\
(1.55)\end{array}$ \\
\hline BIGTRFF & Mimetic & & & & & $\begin{array}{l}0.083^{*} \\
(1.72)\end{array}$ & $\begin{array}{l}0.060 \\
(1.14)\end{array}$ \\
\hline QAIFAC & Normative & & & & & $\begin{array}{l}0.001 \\
(1.18)\end{array}$ & $\begin{array}{l}0.000 \\
(0.58)\end{array}$ \\
\hline \multicolumn{2}{|c|}{ Number of observations } & 54 & 54 & 54 & 324 & 324 & 324 \\
\hline \multicolumn{2}{|c|}{ Number countries } & 54 & 54 & 54 & 54 & 54 & 54 \\
\hline \multicolumn{2}{|c|}{ Pseudo - $\mathbf{R}^{2}$} & 0.3664 & 0.1442 & 0.4965 & 0.3360 & 0.2152 & 0.3915 \\
\hline
\end{tabular}

Notes: This Table reports the logit estimates of single period and multi-period with time-varying covariates for the likelihood of adopting IFRS at country level for different sample size and period in comparison to Judge et al. 2010 and Kossentini \& Othman (2015). Models 5-7 contains results of cross-sectional data using 2008 as adoption year and averages as done in Judge et al. 2010. M5 contains results using our variables. M6 contains results using the Judge et al. variables. Model 7 contains results using our variables and that of Judge et al. (2010). Models 8 10 contain the results of pool-data data from 2005-2010. M8 contains results using our variables. M9 contain results using the Kossentini \& Othman. variables. M10 contains results using our variables and that of Kossentini \& Othman. For variable definitions, see Table 1 and Table 8. Z-statistics are presented in parentheses Stars indicate statistical significance: ${ }^{*} \mathrm{p}<.1, * * \mathrm{p}<.05, * * * \mathrm{p}<.01$. 
Table 7.0. Regression results at firm-level.

\begin{tabular}{|c|c|c|c|c|}
\hline Variables & $\begin{array}{l}\text { Institutional } \\
\text { variables (RE) } \\
\text { M11 }\end{array}$ & $\begin{array}{l}\text { Institutional } \\
\text { variables } \\
\text { (FE) } \\
\text { M } 12\end{array}$ & $\begin{array}{l}\text { Financial } \\
\text { variables } \\
\text { (FE) } \\
\text { M } 13\end{array}$ & $\begin{array}{l}\text { Institutional \& } \\
\text { Financial (FE) } \\
\text { M } 14\end{array}$ \\
\hline $\mathrm{OWT}$ & $\begin{array}{l}0.61 \\
(1.54)\end{array}$ & $\begin{array}{l}0.41 \\
(0.82)\end{array}$ & & $\begin{array}{l}0.35 \\
(1.19)\end{array}$ \\
\hline BIG4 & $\begin{array}{l}1.96^{* * * *} \\
(3.13)\end{array}$ & $\begin{array}{l}2.18 * * * \\
(3.25)\end{array}$ & & $\begin{array}{l}3.13 * * * \\
(4.44)\end{array}$ \\
\hline $\mathrm{CAB}$ & $\begin{array}{l}5.65^{* * *} \\
(3.18)\end{array}$ & $\begin{array}{l}3.73 * * * \\
(2.93)\end{array}$ & & $\begin{array}{l}2.37 * * \\
(1.99)\end{array}$ \\
\hline BS & $\begin{array}{l}1.26 \\
(1.17)\end{array}$ & $\begin{array}{l}0.97 \\
(1.02)\end{array}$ & & $\begin{array}{l}0.71 \\
(1.46)\end{array}$ \\
\hline LS & $\begin{array}{l}4.06^{* * * *} \\
(2.78)\end{array}$ & $\begin{array}{l}3.26 * * * \\
(2.81)\end{array}$ & & $\begin{array}{l}3.21 * * * \\
(2.87)\end{array}$ \\
\hline RG & & & $\begin{array}{l}0.72 * * * \\
(2.32)\end{array}$ & $\begin{array}{l}0.63 * * \\
(1.77)\end{array}$ \\
\hline FR & & & $\begin{array}{l}0.031 \\
(0.98)\end{array}$ & $\begin{array}{l}0.053 \\
(1.27)\end{array}$ \\
\hline LEV & & & $\begin{array}{l}3.15 * * * \\
(5.26)\end{array}$ & $\begin{array}{l}1.73 * * \\
(2.05)\end{array}$ \\
\hline TAA & & & $\begin{array}{l}1.96 * * * \\
(3.99)\end{array}$ & $\begin{array}{l}2.23 * * * \\
(4.61)\end{array}$ \\
\hline Time dummy & Yes & Yes & Yes & Yes \\
\hline Pseudo $\mathrm{R}^{2}$ & & 0.451 & 0.523 & 0.693 \\
\hline Observations & 1,100 & 1,100 & 485 & 485 \\
\hline Firms & 220 & 220 & 97 & 97 \\
\hline
\end{tabular}

Notes: This table reports estimates of multi-period logit models with time-varying covariates for the likelihood of adopting IFRS for at firm level. Except for M11, all models are firm fixed-effects (FE) logit model. The models include all observations available from 2010 to 2015. Explanatory variables are measured contemporaneously with IFRS years, i.e. they are not lagged. $O W T-$ Ownership type $=1$ if the majority shareholder is foreign national or institution or 0 otherwise. BIG4 - $1=$ if the company is audited by Big 4 or 0 , otherwise. $C A B$ - the number of chartered accounts as a percentage of the total board size. $B S$ - board size measured as number of directors. $L S-$ 1 if the firm is listed firm and 0 otherwise. $R G$ - percentage growth in revenue. $F R$ - percentage of sales from organization foreign countries. $L E V-$ debt to capital ratio. $T A A-\log$ of total assets. Z-statistics and are presented in parentheses. Stars indicate statistical significance: $* \mathrm{p}<.1, * * \mathrm{p}<.05, * * * \mathrm{p}<.01$. 
Appendix A. IFRS adoption status of African countries.

\begin{tabular}{|c|c|c|c|}
\hline $\begin{array}{l}\text { Required for all } \\
\text { companies (3) }\end{array}$ & $\begin{array}{l}\text { Required for some } \\
\text { companies (2) }\end{array}$ & Permitted (1) & Not permitted (0) \\
\hline $\begin{array}{l}\text { Botswana }^{1}(2004) \\
\text { Ghana }^{1}(2007) \\
\text { Kenya }^{1}(1999) \\
\text { Lesotho }^{1}(2002) \\
\text { Malawi }^{2}(2002) \\
\text { Mauritius }^{1}(2002) \\
\text { Mozambique }^{2}(2011) \\
\text { Namibia }^{1}(2005) \\
\text { Nigeria }^{1}(2012) \\
\text { Rwanda }^{1}(2009) \\
\text { Sénégal }^{1}(2014) \\
\text { Sierra Leone }^{1}(2009) \\
\text { South Africa } \\
\text { Swaziland }^{1}(2005) \\
\text { Tanzania }^{1}(2004) \\
\text { Uganda }^{1}(1998) \\
\text { Zambia }^{1}(2005) \\
\text { Zimbabwe }^{1}(1996)\end{array}$ & $\begin{array}{l}\text { Eritrea }^{2}(2008) \\
\text { Gambia }^{1}(2013) \\
\text { Liberia }^{2}(2012) \\
\text { Morocco }^{2}(2008) \\
\text { Seychelles }^{4}(2004)\end{array}$ & $\begin{array}{l}\text { Cabo Verde }{ }^{4}(2010) \\
\text { Djbouti }^{4}(2013) \\
\text { Ethopia }^{4}(2005) \\
\text { Libya }^{4}(2005) \\
\text { Madagascar }^{1}(2013) \\
\text { South sudan }\end{array}$ & $\begin{array}{l}\text { Algeria }^{2} \\
\text { Angola }^{1} \\
\text { Benin }^{1} \\
\text { Burkina Faso }^{1} \\
\text { Burundi }^{1} \\
\text { Cameroon }^{1} \\
\text { Central Africa }^{1} \\
\text { Chad }^{3} \\
\text { Comoros }^{1} \\
\text { Congo Republic }^{1} \\
\text { Congo DR }^{1} \\
\text { Cote Divore }^{1} \\
\text { Egypt }^{1} \\
\text { Equatorial Guinea }^{1} \\
\text { Gabon }^{1} \\
\text { Guinea }^{1} \\
\text { Guinea Bissau }^{1} \\
\text { Mali }^{1} \\
\text { Mauritania }^{2} \\
\text { Niger }^{1} \\
\text { Sao Tome }^{3} \\
\text { Somalia }^{4} \\
\text { Sudan }^{4} \\
\text { Togo }^{4} \\
\text { Tunisia }^{3}\end{array}$ \\
\hline
\end{tabular}

Sources:

1. IFRS.org/use around the world.

2. iasplus.com

3. PWC-IFRS adoption by countries

4. Other sources (ROSC (AA, IMF reports, articles Memos, etc)

In some cases, we collect the year of adoption from sources other than the source of adoption status. 
Appendix B. Description of variables used in prior studies

\begin{tabular}{|c|c|c|}
\hline \multicolumn{3}{|c|}{ Judge et al. 2010 variables. } \\
\hline $\begin{array}{l}\text { Coercive } \\
\text { isomorphism }\end{array}$ & $\begin{array}{l}\text { Foreign aid } \\
\text { (FORAID) }\end{array}$ & $\begin{array}{l}\text { It is computed as the average proportion of } \\
\text { foreign aid relative to the gross domestic product } \\
\text { during the } \\
\text { period of } 2003-07\end{array}$ \\
\hline $\begin{array}{l}\text { Mimetic } \\
\text { isomorphism }\end{array}$ & $\begin{array}{l}\text { Import penetration } \\
\text { (IMPT) }\end{array}$ & $\begin{array}{l}\text { we used the average important penetration } \\
\text { from 2003-06. }\end{array}$ \\
\hline $\begin{array}{l}\text { Normative } \\
\text { isomorphism }\end{array}$ & Education (SECON) & $\begin{array}{l}\text { the enrolment in secondary schools as a percentage } \\
\text { of the total population in the age group for } \\
\text { secondary education in } 2004 \text {. }\end{array}$ \\
\hline \multicolumn{3}{|c|}{ Kossentini and Othman (2015) } \\
\hline $\begin{array}{l}\text { Coercive } \\
\text { isomorphism }\end{array}$ & $\begin{array}{l}\text { Interaction of } \\
\text { ROSC and foreign } \\
\text { aid } \\
\text { (FAROSC) }\end{array}$ & $\begin{array}{l}\text { Indicator proxy of ROSC reports } \\
\text { foreign aid as a percentage of GDP }\end{array}$ \\
\hline $\begin{array}{l}\text { Mimetic } \\
\text { isomorphism }\end{array}$ & $\begin{array}{l}\text { Interaction of BIG4 } \\
\text { and Trade freedom } \\
\text { (BIGTRFF) }\end{array}$ & $\begin{array}{l}\text { the number of BIG } 4 \text { offices over the population in } \\
\text { millions. } \\
\text { Trade freedom }\end{array}$ \\
\hline $\begin{array}{l}\text { Normative } \\
\text { isomorphism }\end{array}$ & $\begin{array}{l}\text { Interaction of IFAC } \\
\text { and number of CPA } \\
\text { over the population } \\
\text { in million } \\
\text { (QAIFAC) }\end{array}$ & $\begin{array}{l}\text { we include the indicator proxy of IFAC } \\
\text { membership } \\
\text { we consider the proxy of the number of CPA's over } \\
\text { population in millions as an indicator of accounting } \\
\text { development. }\end{array}$ \\
\hline
\end{tabular}

